\title{
Dampak Covid - 19 Terhadap Kegiatan Industri Rumah Tangga Umkm Di Kecamatan Selong Kabupaten Lombok Timur
}

\author{
Suprianto $^{* 1}$, Eka Agustiani ${ }^{2}$, Soenaryo Neneng ${ }^{3}$ \\ ${ }^{12}$ Fakultas Ekonomi dan Bisnis Universitas Mataram \\ ${ }^{3}$ Fakultas Ekonomi Dan Bisnis Universitas Palangka Raya \\ *Coressponding Email: suprianto@unram.ac.id
}

\begin{tabular}{|c|c|}
\hline Info Artikel & ABSTRAK \\
\hline $\begin{array}{l}\text { Kata Kunci: } \\
\text { Dampak COVID-19 } \\
\text { Terhadap Kegiatan Usaha } \\
\text { Industri Rumah Tangga }\end{array}$ & $\begin{array}{l}\text { Penelitian ini mengambil judul "Dampak COVID-19 Terhadap } \\
\text { Kegiatan Industri Rumah Tangga UMKM di Kecamatan Selong } \\
\text { Kabupaten Lombok Timur".. Tujuan penelitian adalah untuk } \\
\text { menganalisis Pendapatan dan Nilai tambah industri olahan rumah } \\
\text { tangga pada era Covid-19. Metode penelitian dilakukan dengan cara } \\
\text { survey dengan mengambil sampel sebanyak } 15 \text { unit usaha } \\
\text { responden, dan penentuan responden ditentukan secara accidental } \\
\text { dengan melihat karakteristik industri rumah tangga tersebut. } \\
\text { Karakteristik dari pekerja informal dan formal sebagian besar } \\
\text { melakukan kegiatannya dirumah responden dan berjualan ditempat- } \\
\text { tempat keramaian yang padat penduduk dan pengunjung di kota } \\
\text { Selong. Tingkat pendidikan responden rata-rata tamat SMP dan } \\
\text { SMA dengan pengalam berusaha dalam industri olahan makanan } \\
\text { terendah } 3 \text { tahun dan tertinggi } 10 \text { tahun. dengan rata-rata lama } \\
\text { waktu bekerja di atas } 10 \text { jam sehari.. Rata-rata pendapatan yang } \\
\text { diperoleh pekerja informal dibawah Rp 2.000.000 sebanyak } \\
46,67 \% \text { dan } 30,33 \% \text { pendapatannya di atas Rp } 3.000,000 \\
\text { Sedangkan pendapatan responden rata-rata di atas Rp } 4.000 .000 \\
\text { sebanyak } 23 \% \text {. } \\
\text { Secara keseluruhan analisis usaha industri rumah tangga } \\
\text { UMKM, sebanyak } 5 \text { usaha tingkat efisiensinya rendah (R/C Rasio } \\
<1 \text { ) yaitu pada usaha dan selebihnya usaha dari responden R/C } \\
\text { rasio nya }>1 \text {, secara ekonomi usahanya layak untuk diusahakan. } \\
\text { Rata-rata Nilai Tambah usaha industri rumah tangga UMKM } \\
\text { memiliki rasio di atas } 50 \text { ( RNT }>50 \% \text { ) berarti nilai tambah } \\
\text { beberapa usaha industri rumah tangga dikategorikan tinggi ( kisaran } \\
51,58 \text { sampai dengan } 86,46 \% \text { tertinggi) sebanyak } 10 \text { unit usaha } \\
\text { industri rumah tangga olahan UMKM. Rasio Nilai Tambah (RNT) } \\
\text { dibawah } 50 \% \text { sebanyak } 5 \text { unit usaha atau } 33,33 \% \text { dikategorikan } \\
\text { memiliki nilai tambah kategori rendah, seperti olahan makanan } \\
\text { serabi,kerupuk terigu, kue kemerodok, serbat jahe dan kacang } \\
\text { goreng memiliki rasionilai tambah dibawah } 50 \% \text { (RNT < } 50 \% \text { ) }\end{array}$ \\
\hline
\end{tabular}


artinya usaha industri yang dikelola oleh rumah tangga rasio nilai tambahnya rendah

Untuk lebih meningkatkan pendapatan usaha industri olahan rumah tangga UMKM di masa pandemi COVID-19 kususnya lebih meningkatkan pangsa jual produk olahan dengan membuka layanan penjualan sistem digital via internet (go food, go jek ) sehingga omzet penjualannya akan meningkat.

\begin{tabular}{l}
\hline \\
\hline Keywords: \\
Impact of COVID-19 on \\
Home Industry Business \\
Activities
\end{tabular}

This research takes the title "The Impact of COVID-19 on the Activity of Home Industry for MSMEs in Selong Subdistrict, East Lombok Regency." The aim of this research is to analyze the income and added value of the processed household industry in the Covid -19 era. The research method was carried out by means of a survey by taking a sample of 15 business units of respondents, and the determination of the respondents was determined accidentally by looking at the characteristics of the home industry.

The characteristics of informal and formal workers mostly carry out their activities at the respondent's house and sell in crowded places and visitors in the city of Selong. The education level of respondents on average graduated from junior high and high school with experience in doing business in the food processing industry, the lowest is 3 years and the highest is 10 years. with an average length of time working more than 10 hours a day. The average income earned by informal workers is below IDR 2,000,000, - as much as $46.67 \%$ and $30.33 \%$ of their income is above IDR 3,000,000. respondents averaged over $R p .4,000,000$, as much as $23 \%$.

Overall analysis of MSME home industry businesses, as many as 5 businesses have low efficiency levels $(R / C$ ratio $<1)$, namely in the business and the rest of the respondents' businesses, the $R / C$ ratio is $>1$, economically the business is feasible to run. The average added value of MSME home industry businesses has a ratio above $50(R N T>50 \%)$, which means that the added value of several home industry businesses is categorized as high (range 51.58 to $86.46 \%$ highest) as many as 10 home industry business units. MSME processed ladder. Value Added Ratio (RNT) below 50\% of 5 business units or $33.33 \%$ are categorized as having low added value, such as processed pancakes, wheat crackers, kemerodok cakes, ginger sherbet and fried peanuts have added value ratios below $50 \%$ (RNT $<50 \%)$ means that industrial businesses managed by households have a low value-added ratio

To further increase the business income of the MSME household processed industry during the COVID-19 pandemic, in particular, increase the selling share of processed products by opening digital system sales services via the internet (go food, go jek) so that their sales turnover will increase. 
Elastisitas - Jurnal Ekonomi Pembangunan

Vol. 3 No. 1, Mater 2021 


\section{PENDAHULUAN}

\section{Latar Belakang}

Pada akhir April 2020, jumlah infeksi COVID-19 telah melampaui 2,8 juta kasus di seluruh dunia, dengan jumlah kematian mendekati 195.000 , dan 210 negara serta kawasan telah terkena dampaknya.1 Akibatnya, ada semakin banyak inisiatif nasional atau lokal yang telah diambil demi mencegah penyebaran virus yang mematikan tersebut. Sementara menunggu penemuan vaksin dan pengobatannya, jaga jarak fisik tetap menjadi satusatunya cara untuk memutus rantai penularan dan melindungi sebagian besar penduduk. Oleh karena itu tindakan karantina penuh atau parsial saat ini sedang diterapkan di seluruh dunia, yang mempengaruhi lebih dari 5 miliar orang. Diperkirakan bahwa langkahlangkah ini akan membawa dampak signifikan pada 1,6 miliar pekerja informal, dengan perempuan yang terlalu banyak terwakili di sektorsektor yang paling terpukul.2 Banyak perempuan dan laki-laki di sektor informal membutuhkan penghasilan demi menafkahi diri sendiri dan keluarga mereka, mengingat kebanyakan dari mereka tidak dapat bergantung pada kompensasi penggantian pendapatan atau tabungan. Tidak bekerja dan tinggal di rumah berarti kehilangan pekerjaan dan mata pencarian. "Mati karena kelaparan atau karena virus" adalah dilema yang terlalu nyata yang harus dihadapi banyak pekerja di sektor perekonomian informal. Yang menyedihkan adalah kita sedang membicarakan jumlah pekerja yang banyak.

Pada tahun 2020, lebih dari 2 miliar pekerja mendapatkan penghasilannya di sektor ekonomi informal. Ini adalah 62 persen dari semua orang yang bekerja di seluruh dunia. Lapangan kerja informal mewakili 90 persen dari total lapangan kerja di negara-negara berpenghasilan rendah, 67 persen di negara-negara berpenghasilan menengah dan 18 persen di negara-negara berpenghasilan atas.
Perempuan lebih banyak terpapar pada sektor informal di negara-negara berpenghasilan rendah dan menengah ke bawah, dan seringkali berada dalam situasi yang lebih rentan dibandingkan rekan lakilaki mereka. Hal serupa terlihat juga di perusahaan informal, yang merupakan delapan dari setiap sepuluh perusahaan di dunia. Perusahaan informal biasanya merupakan unit skala kecil yang tidak terdaftar, yang seringkali mempekerjakan sepuluh atau lebih sedikit pekerja berketerampilan rendah dan yang tidak didaftarkan, termasuk pekerja keluarga yang tidak dibayar, terutama perempuan, yang bekerja dalam kondisi rentan, tanpa perlindungan sosial atau langkah-langkah keselamatan dan kesehatan di tempat kerja. Mereka memiliki produktivitas rendah, tingkat tabungan dan investasi yang rendah.

Pengembangan industri berbasis pertanian (agroindustri) cukup strategis untuk dijadikan prioritas oleh pemerintah Indonesia , karena industri ini pada umumnya mengandalkan sumber daya hasil pertanian yang tidak tahan lama (perishable), mudah busuk (bulky), bersifat musiman dan tingkat teknologi yang masih sederhana. Agroindustri mempunyai peranan strategis dalam upaya pemenuhan kebutuhan pokok, perluasan kesempatan kerja, pemberdayaan produksi dalam negeri, perolehan devisa, pengembangan sektor ekonomi lainnya dan perbaikan perekonomian masyarakat pedesaan. Struktur agroindustri di Indonesia didominasi oleh industri rumah tangga dengan pangsanya berkisar 90 persen dari total agroindustri. Namun sayangnya, produktivitas tenaga kerja agroindustri skala kecil relatif lebih kecil bila dibandingkan dengan produktivitas industry besar. Hal ini disebabkan berbagai faktor antara lain tingkat pendidikan dan keterampilan tenaga kerja yang relatif rendah dan tingkat teknologi yang masih sederhana (Supriyati dan Suryani, 2006).

Pengembangan industri pengolahan pangan di Indonesia yang didukung oleh 
sumberdaya alam pertanian, baik nabati maupun hewani yang mampu menghasilkan berbagai produk olahan yang dapat dibuat dan dikembangkan dari sumber daya alam lokal atau daerah. Saat ini di beberapa negara Asia banyak produk pangan yang diangkat dari jenis pangan lokal dan diolah secara tradisional. Dengan berkembangnya produk lokal tersebut, maka jumlah dan jenis produk pangan menjadi semakin banyak jumlahnya (Soleh, 2003). Sumberdaya alam pertanian menghasilkan berbagai produk olahan yang dapat dibuat dan dikembangkan dari sumber daya alam lokal atau daerah. Produk pangan di negara Asia banyak yang diangkat dari jenis pangan lokal dan diolah secara tradisional umumnya berbahan dasar tepung tapioka. Tepung tapioka, tepung singkong, tepung kanji, atau aci adalah tepung yang diperoleh dari umbi akar ketela pohon singkong.

Daerah Provinsi Nusa Tenggara Barat merupakan daerah penghasil produkproduk pertanian yang cukup banyak selain padi yang merupakan lumbung nasional dan produk hortikultura lainnya. Salah satu kabupaten yang memiliki jumlah penduduk yang tinggi dengan luas wilayah yang sebahagian besar merupakan lahan sawah pertanian adalah kabupaten Lombok Timur merupakan salah satu daerah yang menjadi lumbung pangan bagi Provinsi Nusa Tenggara Barat. Sektor pertanian masih menjadi salah satu sektor unggulan bagi daerah ini karenanya tidak heran apabila sektor pertanian masih menjadi motor penggerak didalam laju pertumbuhan ekonomi. Seiring dengan perkembangan teknologi informasi, balai pelatihan swasta maupun pemerintah dengan pesatnya memberikan arahan kepada masyarakat untuk menginovasikan hasil pertanian sehingga menghasilkan nilai tambah. Agroindustri olahan di era ketatnya persaingan usaha sekarang ini menjadi solusi terutama bagi para pengusaha berskala micro. Potensi sumberdaya alam yang dimiliki daerah cukup mendukung baik dari segi sumberdaya alam maupun sumber daya manusa bahkan factor-faktor produksi lainnya.

Pada Agroindustri olahan di berbagai kecamatan yang ada dikabupaten Lombok timur, lebih tepatnya terdapat di Kecamatan Labuhan Haji, Kecamatan Montong Gading, Kecamatan Pringgabaya, Kecamatan Pringgasela, kecamatan Sakra, Kecamatan Selong, Kecamatan Sembalun, Kecamatan Sikur, Kecamatan Suralaga, Kecamatan Suela, dan Kecamatan Wanasaba. Produsen dalam kegiatan agroindustri olahan tersebut mulai dari para petani, masyarakat non petani dengan berbagai profesi turut andil dalam bidang agroindustri olahan berskala rumah tangga. Namun dalam hal ini tak hanya pada produk pangan akan tetapi juga pengolahan yang menghasilkan produk-produk makanan industri rumah tangga UMKM yang cukup banyak dikembangkan di Kabupaten Lombok Timur. Salah satunya di kecamatan Selong yang menjadi daerah penelitian terkait tentang "Dampak COVID -19 terhadap kegiatan industri rumah tangga UMKM yang mengolah berbagai macam produk olahan berbahan baku dari hasil pertanian.. Pengembangan agroindustri UMKM diharapkan dapat meningkatkan nilai tambah komoditas pertanian. Maka dari itu dapat meningkatkan pendapatan dan kesejahteraan petani yang berskala rumah tangga (home industry). Usaha agroindustri olahan rumah tangga di Kabupaten Lombok Timur merupakan usaha yang menerapkan manajemen yang sederhana, dimana pengelolaan usaha tersebut sangat didominasi oleh pemilik usaha agroindustri tahu itu sendiri. Efisiensi usaha agroindustri tersebut dapat diketahui ketika usaha dapat mengelola penggunaan sarana produksi secara hemat. Tingkat efisiensi dapat digunakan sebagai tolok ukur dalam pengelolaan sarana produksi saat kegiatan proses pembuatan produk berlangsung. Ketika suatu usaha telah efisien secara teknis, maka pendapatan usaha akan meningkat. Kegiatan produksi ini 
memperoleh penerimaan yaitu dengan mengalikan total produksi dengan harga produksi. Hasil perhitungan penerimaan kemudian dikurangi dengan biaya total sehingga diperoleh pendapatan.

\section{Rumusan Masalah}

Mengacu pada gambaran latar belakang tersebut di atas maka dapat ditarik beberapa permasalahan yaitu sebagai berikut :

a. Bagaimana profil industri olahan rumah tangga UMKM di kecamatan Selong kabupaten Lombok Timur pada masa pandemi COVID - 19.

b. Berapa besaran biaya, penerimaan dan keuntungan dari usaha industriw olahan rumah tangga di Kabupaten Lombok Timur?

c. Bagaimana efisiensi dan nilai tambah dari usaha industri olahan rumah tangga di kecamatan Selong Kabupaten Lombok Timur?

\section{Tujuan Penelitian}

a. Untuk mengetahui profil usaha industri rumah tangga UMKM di masa COVID19 di kecamatan Selong Kabupaten Lombok Timur.

b. Untuk menganalisis besarnya biaya, penerimaan dan keuntungan dari usaha agroindustri olahan rumah tangga di Kabupaten Lombok Timur.

c. Untuk menganalisis efisiensi dari usaha agroindustri olahan rumah tangga di Kabupaten Lombok Timur.

\section{TINJAUAN TEORI}

\section{Pengertian Industri Rumah Tangga UMKM}

Pengertian industri yang dimaksud di sini lebih menekankan pada unit usaha yang merubah bentuk barang atau dengan kata lain dengan melakukan proses produksi yang bukan menekankan pada kumoulan firma yang menghasilkan barang /produk sejenis. Industri kecil yang termasuk didaamnya industri informal umumnya mempunyai usaha berskala kecil bik yang berada di perkotaan maupun yang ada di tingkat pedesaan dengan kondisi yang relative terbatas (Rukmini ; 2013 ). Secara kuantitas industri ini cenderung bertambah, namun tidak berate tidak ada yang gulungtikar. Banyak yang gulung tikar namun banyak juga yng muncul. Hal ini karena modal yang diperlukan relative kecil sehingga mereka mudah masuk tetapi dengan kemampuan yang belum dapat diandalkan maka semudah itu pula mereka keluar atau gulungtikar.

Umumnya masalah yang dihadapi Industri kecil (IK) dan Industri Rumah tangga (IRT) adalah sebagai berikut:

a. Kurang mampu di bidang manajemen.

Dalam era sekarang, manajemen merupakan salah satu kunci keberhasilan organisasi.Memang pada manajemen industri kecil dan industri rumah tangga tidak akan mampu menyamai dengan manajemen pada manajemen industri besar dan menengah namun bagaimanapun seorang leader tetapi dituntut dapat mengelolausaha terutama melalui usaha kemampuannya memanage orang lain dalam organisasinya. Kekurangmampuan dalam bidang manajemen dapat berakibat cukup fatal terutama tingkat efisiensi yang rendah. Terutama dari segi biaya sedangkan efisiensi biaya merupakan modal utam untuk bersaing dalam harga jual produk, kemudian produktivitas juga rendah. Catatan dan atau pembukuan sederhana tentang arus keluar masuknya uang tidak ada, control relative kurang dan lain-lain.

b. Ketrampilan rendah.

Pada IK dan IRT yang bersifat labor intensif, ketrampilan tenaga kerja sangat diutamkan karena inilah yang pada akhirnya akan mempengaruhi kemampuan dalam menghasilkan produk berkualitas. Selain itu melalui 
ketrampilan yang relative dapat diandalkan disertai kemampuan menlorkan beberapa ide baru diharapkan akan menghasilkan desain dan diversivikasi produk yang diandalkan.

c. Modal relative kecil.

Walaupun dari kacamata kita (bukan produsen) modal kadang-kadang bukan merupakan masalah utama, namun fakta menunjukkan bahwa sebagaian dari IK dan IRT mengalami masalah di wbidang keuangan. Mau mencari pinamam dari lembaga-lembaga tidak bias karena tidak mempunyai agunan sedangkan tingkat usaha dirasakan kecil. Lagipula sebagian dan bahkan seluruh keuntungan yang sedikit ini digunakan untuk konsumsi/makan keluarga seharihari. Akibatnya pengembangan usaha kedepan akan sulit untuk dilaksanakan.

d. Jiwa wiraswasta renda.

Keadaan ini tercermin melalui beberapa observasi dilapangan yang menunjukkan kurang ide/pemikiran untuk menghadapi hari esok yang cemerlang dalam usaha mereka. Mereka cenderung hanya berproduksi kemudian berjualan dan setelah habis kegiatan tersebut berarti habis pula aktivitas dan pemikiran mereka. Begitu keadaan sehari-hari yang dialaminya. Sebagian dari produsen industri kecil dan industri rumah tangga(IRT) yang terjun di bidang ini bukan karena kemampuan dan kejelian menangkap peluang, melainkan hanya ikut-ikutan.

e. Dilihat dari jenis produk, tidak semua industri kecil (IK) dan IRT bepotensi yang sama untuk maju berkembang. Ada jenis produk tertentu dapat menembus pasar sehingga ke luar negeri namun banyak pula yang hanya berproduksi untuk memenuhi pasar di sekitarnya saja. Akibatnya sebagian dari iK dan IRT hanya bertahan untuk hidup dan bahkan kaang-kadang gulung tikar. f. Dilihat dari segi aktivitas penjualan, tampaknya sebagian besar unit usaha IK dan IRT bekerja sendiri-sendiri dan hamper tidak ada jaringan usaha mapan yang menjamin kelancaran usaha.

\section{Pengertian Agroindustri}

Menurut Manalili (1996) dan Sajise (1996), agroindustri adalah fase pertumbuhan setelah pembangunan pertanian. Jadi, setelah pembangunan pertanian diikuti dengan pembangunan agroindustri kemudian pembangunan industri. Sementara itu, ahli yang lain (Soeharjo, Soekartawi, dan Badan Agribisnis DEPTAN) menyebutkan bahwa agroindustri adalah pengolahan hasil pertanian dan merupakan bagian dari enam subsistem agribisnis yang disepakati selama ini yaitu subsistem penyediaan sarana produksi dan peralatan, usaha tani, pengolahan hasil (agroindustri), pemasaran, sarana dan pembinaan (Soekartawi, 2000: 9). Agroindustri dapat diartikan dua hal. Pertama, agroindustri adalah industri yang berbahan baku utama dari produk pertanian. Studi agroindustri pada konteks ini adalah menekankan pada food processing management dalam suatu perusahaan produk olahan yang bahan baku utamanya adalah produk pertanian. Menurut FAO, suatu industri yang menggunakan bahan baku dari pertanian dengan jumlah minimal $20 \%$ dari jumlah bahan baku yang digunakan disebut agroindustri. Arti yang kedua, agroindustri dapat diartikan sebagai suatu tahapan pembangunan sebagai kelanjutan dari pembangunan pertanian, tetapi sebelum tahapan pembangunan tersebut mencapai tahapan pembangunan industri(Soekartawi, 2000).

Menurut Soekartawi (2000: 17), pembangunan agroindustri merupakan kelanjutan dari pembangunan pertanian. Bila pembangungan pertanian berhasil, maka pembangunan agroindustri pun berhasil. Begitu pula sebaliknya. Sehingga agroindustri memiliki peran dalam 
perekonomian nasional. Berikut ini peran agroindustri dalam perekonomian nasional:

a. Mampu meningkatkan pendapatan pelaku agribisnis khususnya dan pendapatan masyarakat pada umumnya.

b. Mampu menyerap tenaga kerja

c. Mampu meningkatkan perolehan devisa.

d. Mampu menumbuhkan industri yang lain, khususnya industri pedesaan.

\section{Pengertian Usaha Kecil Menengah}

Pengertian mengenai Usaha Kecil menurut Undang-Undang Nomor 20 tahun 2008 adalah usaha ekonomi produktif yang berdiri sendiri, yang dilakukan oleh orang perorangan atau badan usaha yang bukan merupakan anak perusahaan atau bukan cabang perusahaan yang dimiliki, dikuasai, atau menjadi bagian baik langsung maupun tidak langsung dari usaha menengah Prosiding Seminar Hilirisasi Penelitian Untuk Kesejahteraan Masyarakat Lembaga Penelitian Universitas Negeri Medan, 28 September 2017449 atau usaha besar yang memiliki kekayaan bersih lebih dari $\mathrm{Rp}$ 50.000.000 (lima puluh juta rupiah) sampai dengan paling banyak Rp500.000.000 (lima ratus juta rupiah) tidak termasuk tanah dan bangunan tempat usaha; atau mememiliki hasil penjualan tahunan lebih dari Rp.300.000.000 (tiga ratus juta rupiah) sampai dengan paling banyak Rp2.500.000.000 (dua milyar lima ratus juta rupiah). Menurut undang-undang usaha kecil menengah Tahun 2008, usaha kecil adalah usaha ekonomi produktif yang berdiri sendiri, yang dilakukan oleh orang perorangan atau badan usaha yang bukan merupakan anak perusahaan atau bukan cabang perusahaan yang dimiliki, dikuasai,atau menjadi bagian baik langsung maupun tidak langsung dari Usaha Menengah atau Usaha Besar yang memenuhi kriteria Usaha Kecil. Kriteria Usaha Kecil adalah sebagai berikut:

- Memiliki kekayaan bersih lebih dari Rp50.000.000 (lima puluh juta rupiah) sampai dengan paling banyak Rp500.000.000 (lima ratusjuta rupiah) tidak termasuk tanah dan bangunan tempat usaha; atau

- Memiliki hasil penjualan tahunan lebih dari Rp300.000.000,00 (tiga ratus juta rupiah) sampai dengan paling banyak Rp2.500.000.000,00 (dua milyar lima ratus juta rupiah).

Selain itu Badan Pusat Statistik (BPS), usaha kecil menengah identik dengan industri kecil dan industri rumah tangga. Badan Pusat statistik mengklasifikasikan industri berdasarkan jumlah pekerjanya, yaitu: (1) industri rumah tangga dengan pekerja 1-4 orang; (2) industri kecil dengan pekerja 5-19 orang; (3) industri menengah dengan pekerja 2099 orang; (4) industri besar dengan pekerja 100 orang atau lebih (BPS, 1995). Hambatan yang dihadapiusaha kecil yaitu sumber daya manusia, keterbatasan modal,pemasaran,saluran distribusi, pengadaan bahan baku dan keterbatasan akses informasi mengenai peluang pasar. Modal yang digunakan usaha kecil berasal dari uang/ tabungan sendiri, akibat rumitnya persyaratan kredit dan tingginya suku bunga kredit menyebabkan usaha kecil kesulitan untuk mengakses kredit ke perbankan.

Menurut Todaro (2000) sektor informal pada umumnya ditandai oleh beberapa karakteristik seperti kegiatan produksi barang dan jasa, berskala kecil, unit produksinya dimiliki secara perorangan atau keluarga, banyak menggunakan tenaga kerja (padat karya), dan teknologi yang dipakai relative sederhana. ILO (1991) melaporkan bahwa $60 \%$ buruh di kota-kota negara berkembang diserap oleh sektor informal dan kegiatan pada usaha kecil dan menengah. Dilaporkan juga bahwa peran sektor usaha kecil menengah sangat penting karena mampu menciptakan pasar-pasar, mengembangkan perdagangan, mengelola sumber alam, mengurangi kemiskinan, membuka lapangan kerja, membangun masyarakat dan menghidupi keluarga mereka tanpa kontrol dan fasilitas dari pihak pemerintah 
daerah yang memadai. 2. Permasalahanpada Usaha Industri Kecil Permasalahan yang timbul dalam pengembangan industri kecil dan rumah tangga adalah pengadaan bahan baku, modal, manajemen dan pemasaran (Apretty, 2000).

Permasalahan dalam pengadaan bahan baku disebabkan karena berbagai hal, antara lain sifat produk pertanian yang musiman, tingkat keragaman yang tinggi, jumlah produksi yang melimpah pada suatu waktu, mudah rusak dan tidak tahan lama. Dari segi pemasaran, pengusaha belum mengembangkan produknya pada mutu dan standar yang baku, kemampuan mendesain produk yang masih rendah, pengiriman kurang tepat, serta belum dapat memenuhi kuantitas produk yang diinginkan oleh konsumen. Pada saat ini persaingan produk semakin marak, perkara kualitas produk sangat penting untuk di tonjolkan maka konsekuensi logisnya adalah bahwa kualitas produk dapat bergeser oleh kualitas produk jenis lainnya. Permasalahan lain yang sering dihadapi oleh usaha kecil dan rumah tangga adalah rendahnya kemampuandalam mengakses kepada sumber- sumber permodalan, baik yang Prosiding Seminar Hilirisasi Penelitian Untuk Kesejahteraan Masyarakat Lembaga Penelitian Universitas Negeri Medan, 28 September 2017

\section{Efisiensi Teknis}

Efisiensi merupakan suatu cara yang digunakan dalam proses produksi, dengan menghasilkan output yang maksimal. Menekan pengeluaran produksi serendah-rendahnya terutama bahan baku, atau dapat, menghasilkan output produksi yang maksimal dengan sumberdaya yang terbatas (Doll dan Orazem, 1984).

Efisiensi teknis akan tercapai bila pengusaha mampu mengalokasikan faktor produksi sedemikian rupa sehingga hasil yang tinggi dapat dicapai. Pengusaha meningkatkan hasilnya dengan cara menekan harga faktor produksi, dan menjual hasilnya dengan harga yang tinggi, maka pengusaha tersebut melakukan efisiensi teknis dan efisiensi harga yang bersamaan. Situasi yang demikainan sering disebut dengan istilah efisiensi ekonomi. Pengusaha melakukan in efisiensi ekonomi sekaligus juga melakukan efisiensi teknis dan efisiensi harga ( Daniel; 2002).

Konsep efisiensi dari aspek ekonomis dinamakan konsep efisiensi ekonomis atau efisiensi harga dalam teori ekonomi produksi , pada umumnya menggunakan konsep ini. Dipandang dari konsep efisiensi ekonomis, pemakaian faktor produksi dikatakan efisiensi apabila dapat menghasilkan keuntungan maksimum. Untuk menentukan tingkat produksi optimum menurut konsep efisiensi ekonomis, tidak cukup hanya mengetahui fungsi produksi. Ada syarat lagi yang harusdiketahui, yaitu rasio harga-harga input output (Hanani: 2011).

Menurut Miller dan Meiners (2000), efisiensi teknis (technical efficiency) mengharuskan atau mensyaratkan adanya proses produksi yang dapat memanfaatkan input yang lebih sedikit demi menghasilkan output dalam mjumlah yang sama. Seorang produsen akan lebih efisien secara teknis daripada produsen lainnya apabila secara konsisten mampu menghasilkan produk yang lebih tinggi dengan menggunakan input produksi yang sama.

\section{Teori Nilai Tambah}

Komoditi pertanian pada umumnya dihasilkan sebagai bahan mentah dan mudah rusak, sehingga perlu langsung dikonsumsi atau diolah terlebih dahulu. Proses pengolahan ini dapat meningkatkan guna bentuk komoditi-komoditi pertanian. Kesediaan konsumen membayar harga output agroindustri pada harga yang relatif tinggi merupakan intensif bagi perusahaanperusahaan pengolah untuk menghasilkan output agroindustri. Kegiatan agroindustri ini meningkatkan guna bentuk komoditikomoditi pertanian yang membutuhkan biaya pengolahan. 
Salah satu konsep yang sering digunakan untuk membahas pengolahan komoditi pertanian ini adalah nilai tambah (Sudiyono, 2002: 147).

Komoditi pertanian pada umumnya dihasilkan sebagai bahan mentah dan mudah rusak, sehingga perlu langsung dikonsumsi atau diolah terlebih dahulu. Proses pengolahan ini dapat meningkatkan guna bentuk komoditi-komoditi pertanian. Kesediaan konsumen membayar harga output agroindustri pada harga yang relatif tinggi merupakan intensif bagi perusahaanperusahaan pengolah untuk menghasilkan output agroindustri. Kegiatan agroindustri ini meningkatkan guna bentuk komoditikomoditi pertanian yang membutuhkan biaya pengolahan. Salah satu konsep yang sering digunakan untuk membahas pengolahan komoditi pertanian ini adalah nilai tambah (Sudiyono, 2002: 147).

Keseimbangan konsumen akibat kegiatan agroindustri hilir dapat dijelaskan dengan metode atribut. Metode atribut menjelaskan bahwa konsumen menderivasikan utiliti suatu barang dari atribut-atribut yang melekat pada barang tersebut. Keseimbangan konsumen dalam proses konsumsi pangan dipengaruhi oleh pendapatan, harga barang perunit dan atribute rating. Konsumen memperhatikan atribut keamanan pangan, nutrisi, nilai dan pengepakan/pengemasan. Berdasarkan penelitian yang dilakukan konsumen bersedia membayar produk olahan yang lebih mahal dibanding produk yang belum diolah karena konsumen dapat mencapai tingkat kepuasan yang lebih tinggi dari sebelumnya. Oleh karena itu , pengolahan dapat menggeser keinginan konsumen yang awalnya memilih produk yang belum diolah ke produk olahan sehingga pengolah dapat meningkakan nilai tambah (Sudiyono;2002).

Menurut Hayami (1987) dalam Soediyono (2002) , ada dua cara untuk menghitung nilai Tambah, yaitu nilai tambaha untuk pengolahan dan nilai tambah untuk pemasaran. Faktor -faktor yang mempengaruhi nilai tambah untuk pengolahan dapat dikategorikan menjadi dua yaitu faktor teknis dan faktor pasar. Faktor teknis yang berpengaruh adalah kapasitas produksi, jumlah bahan baku yang digunakan dan tenaga kerja, harga bahan baku dan input lain selain bahan bakar dan tenaga kerja.

Besarnya nilai tambah karena proses pengolahan didapat dari pengurangan biaya bahan baku dan input lainnya terhadap nilai produk yang dihasilkan, tidak termasuk tenaga kerja. Dengan kata lain, nilai tambah menggambarkan imbalan bagi tenaga kerja, modal dan manajemen. Secara matematik dapat digambarkan sebagai berikut (Sudiyono, 2002: 149-150):

Nilai tambah $=\mathrm{f}(\mathrm{K}, \mathrm{B}, \mathrm{T}, \mathrm{U}, \mathrm{H}, \mathrm{h}, \mathrm{L})$

Dimana :

$\mathrm{K}=$ Kapasitas produksi

$\mathrm{B}=$ Bahan baku yang digunakan

$\mathrm{T}=$ Tenaga kerja yang digunakan

$\mathrm{U}=$ Upah tenaga kerja;

$\mathrm{H}=$ Harga output;

$\mathrm{h}=$ Harga bahan baku

$\mathrm{L}=$ Nilai input lain (nilai dan semua korbanan yang terjadi selama proses perlakuan untuk menambah nilai )

\section{Penelitian Terdahulu}

Penelitian yang telah dilakukan oleh Arif Budiman, Jum'atri Yusri, Ermi Tety (2012) yang berjudul "Analisis Efisiensi dan Nilai Tambah Agroindustri Tahu di Kota Pekanbaru". Hasil penelitiannya yaitu Nilai tambah yang diperoleh dari tahu ukuran kecil adalah sebesar Rp.7.607,69/kg. Nilai tambah ini diperoleh dari pengurangan nilai output (produksi tahu ukuran kecil) dengan biaya bahan baku dan biaya bahan penunjang lainnya. Sedangkan rasio nilai tambah tahu ukuran kecil adalah sebesar 51,49\%, artinya 51,49 persen dari nilai output (tahu kecil) merupakan nilai tambah yang diperoleh dari pengolahan agroindustri tahu. Sedangkan nilai tambah yang diperoleh dari tahu ukuran besar adalah sebesar Rp.5.578,80/kg. Nilai tambah ini diperoleh 
dari pengurangan nilai output (produksi tahu ukuran besar) dengan biaya bahan baku dan biaya bahan penunjang lainnya. Sedangkan rasio nilai tambah tahu ukuran besar adalah sebesar $43,77 \%$, artinya 43,77 persen dari nilai output (tahu besar) merupakan nilai tambah yang diperoleh dari pengolahan agroindustri tahu. Dan Usaha agroindustri tahu sudah efisien karena nilai $\mathrm{R} / \mathrm{C}$ rasio lebih dari satu yaitu sebesar 1,39 berarti bahwa setiap Rp.1,00 biaya yang dikeluarkan dalam usaha agroindustri tahu memberikan penerimaan sebesar 1,39 kali dari biaya yang telah dikeluarkan.

Penelitian yang dilakukan oleh Prof. Dr. Ir. Irham, M.Sc.; Dr. Jangkung Handoyo Mulyo, M.Ec. (2018) yang berjudul "Nilai Tambah dan Efisiensi Olahan Pisang di Daerah Perbatasan Pulau Sebatik Kabupaten Nunukan Kalimantan Utara". Metode yang digunakan dalam penelitian ini adalah, nilai tambah metode Hayami untuk mengetahui besarnya nilai tambah. Hasil kajian terhadap nilai tambah berbagai macam olahan pisang didaerah perbatasan pulau sebatik menunjukkan bahwa proses pengolahan pada komoditi pisang memberikan nilai tambah rata-rata sebesar $\mathrm{Rp} 16.375,28 / \mathrm{Kg}$ dengan rata-rata keuntungan adalah Rp6.015,83/Kg. Analisis efisiensi relatif terhadap $15 \mathrm{DMU}$ agroindustri olahan pisang menunjukkan bahwa sebagian besar agroindustri olahan pisang di daerah perbatasan Pulau Sebatik belum efisien. Sebanyak $40 \%$ agroindustri olahan pisang efisien dan $60 \%$ inefisien. Rata-rata nilai efisiensi relatif agroindustri olahan pisang adalah 0,737 .

Azwar Saihani \& Siti Hapizah (2015) telah melakukan penelitian yang berjudul "Analisis wNilai Tambah dan Efisiensi Usaha Tape Ketan pada agroindustri Rumah Tangga Tape Ketan di Desa Sungai Karias Kecamatan Amuntai Tengah Kabupaten Hulu Sungai Utara". Nilai tambah yang diperoleh dari industri rumah tangga tape ketan adalah sebesar Rp. $15.574,7 / \mathrm{kg}$, rasio nilai tambah tape ketan adalah sebesar 51,83\%, besar keuntungan Rp.14.596,3/kg atau tingkat keuntungan sebesar $93,71 \%$ dari nilai produk. Efisiensi Usaha pada industri rumah tangga tape ketan di Desa Sungai Karias sebesar 2,00 yang berarti bahwa industri tape ketan yang dijalankan sudah efisien, Nilai $\mathrm{R} / \mathrm{C}$ rasio 2,00 berarti bahwa setiap Rp.1,00 biaya yang dikeluarkan dalam usaha industri rumah tangga tape ketan memberikan penerimaan sebesar 2,00 kali dari biaya yang telah dikeluarkan.

\section{METODOLOGI PENELITIAN}

\section{Jenis Penelitian}

Penelitian ini menggunakan metode analisis deskriptif yaitu untuk meneliti status kelompok manusia, suatu obyek, suatu set kondisi, suatu sistem pemikiran ataupun suatu kelas peristiua pada masa sekarang (Nazir; 2011). Metode deskriptif menggambarkan peristia secara sistematis, faktual dan akurat mengenai fakta, sifat dan hubungan antar fenomena yang diteliti. Penelitian ini bertujuan untuk membuat gambaran atau lukisan secara sistimatis , faktual dan akurat mengenai usaha industri rumah tangga (UMKM) di Kecamatan Selong Kabupaten Lombok Timur.

\section{Tempat dan Waktu Penelitian}

Penelitian ini dilakukan di Kabupaten Lombok Timur dengen mengambil objek penelitian adalah pengusaha dalam bidang agroindustri olahan berskala rumah tangga(UMKM) di Kecamatan Selong. Alasan penentuan tempat penelitian kecamatan Selong berada di ibukota Lombok Timur yang merupakan pusat keramaian dan perdagangan sehingga produk industri rumah tangga ini cepat untuk dipasarkan atau dijual.

\section{Penentuan Sampel}

Populasi dari penelitian ini adalah usaha agroindustri olahan rumah tangga yang ada di kecamatan Selong Kabupaten Lombok Timur. Karena besaran populasi tidak 
diketahui maka digunakan teknik pengambilan sampel nonprobability sampling yaitu dengan mengambil sebanyak 15 responden usaha industri kecil rumahan (home industri). Metode yang digunakan untuk penarikan sampel ialah snowball sampling. Teknik snowball sampling (bola salju) adalah metoda sampling di mana sampel diperoleh melalui proses bergulir dari satu responden ke responden yang lainnya. Pengambilan sampel dengan metode ini dapat dilakukan dengan cara mencari contoh sampel dari populasi yang diinginkan, kemudian dari sampel yang didapat dimintai partisipasinya untuk memilih komunitasnya sebagai sample lagi. Seterusnya sehingga jumlah sampel yang diinginkan terpenuhi (Arikunto; 2006)

\section{Jenis Data dan Teknik Pengumpulan Data}

Jenis data yang digunakan adalah data sekunder data data primer. Data primer didapatkan dari wawancara langsung dengan responden menggunakan kuisioner. Data primer yang diambil meliputi: identitas responden mencakup (nama, umur, jenis kelamin, pendidikan, tanggungan, lama usaha, dan alamat), data karakteristik usaha, data aspek financial, data biaya produksi, hingga data proses produksi. Teknik pengumpulan data dengan melakukan observasi dan metode wawancara yang berpedoman pada daftar pertanyaan yang telah disiapkan.

\section{Model Analisis Data}

Analisis data yang digunakan dalam penelitian ini adalah analisis kualitatif dan kuantitatif. Analisis kualitatif dipakai untuk mendapatkan gambaran kondisi usaha agroindustri olahan rumah tangga. Analisis kuantitatif digunakan untuk melihat analisis usaha dan beberapa perhitungan yang dilakukan dalam penelitian ini. analisis kuantitatif berupa analisis nilai rata-rata penyusutan alat, biaya produksi, nilai produksi, keuntungan, profitabilitas, analisis efisiensi usaha dan nilai tambah.

\section{Penyusutan Peralatan}

Penyusutan peralatan merupakan penurunan nilai alat dalam jangka waktu tertentu. Biaya penyusutan peralatan dihitung dengan metode garis lurus dengan rumus sebagai berikut:

\section{Penyusutan $=$ HP - NS $/$ Umur Ekonomis}

Keterangan:

$\mathrm{HP}=$ Nilai perolehan atau nilai beli peralatan $(\mathrm{Rp})$

$\mathrm{NS}=$ Nilai Sisa $(\mathrm{Rp})$

$\mathrm{UN}=$ Umur Ekonomis (tahun)

\section{Biaya Produksi}

Biaya produksi dalam usaha agroindustri olahan terdiri dari biaya variabel (variable cost) dan biaya tetap (fixed cost). Biaya variabel (variable cost) terdiri dari biaya pembelian bahan baku, pembelian bahan penolong, tenaga kerja, dan bahan bakar. Biaya tetap (fixed cost) terdiri dari biaya penyusutan peralatan, biaya sewa tempa produksi, biaya air dan biaya listrik.

Biaya total merupakan penjumlahan antara biaya tetap total (TFC) dan biaya variabel total (TVC). Furmulasi biaya total sebagai berikut: $\boldsymbol{T C}=\boldsymbol{T F} \boldsymbol{C}+\boldsymbol{T} \boldsymbol{V C}$

Keterangan:

$\mathrm{TC}=$ Biaya total usaha agroindustri olahan rumah tangga (Rp/bulan)

TFC = Total biaya tetap usaha agroindustri olahan rumah tangga ( $\mathrm{Rp} /$ bulan)

TVC = Total biaya variabel usaha agroindustri olahan rumah tangga (Rp/bulan)

\section{Nilai Produksi}

Menurut BPS, nilai produksi adalah nilai dari komoditas yang dihasilkan oleh sektor produksi, biasanya merupakan hasil perkalian dari kuantitas produksi dengan harga per unit komoditas tersebut. Dalam 
penelitian ini nilai produksi disamakan dengan nilai penerimaan atau pendapatan usaha agroindustri olahan rumah tangga selama 1x produksi.

Penerimaan total (total revenue) dari suatu usaha dapat diperoleh dari hasil perkalian antara jumlah produksi yang dihasilkan dengan harga jual produk. Secara matematis penerimaan ditulis dengan rumus:

\section{$\boldsymbol{T} \boldsymbol{R}=\boldsymbol{P} \times \boldsymbol{Q}$}

Dimana:

$\mathrm{TR}=$ Total Revenue (total penerimaan Usaha Industri Rumah Tangga UMKM dalam Rp)

$\mathrm{P} \quad=$ Harga produk $(\mathrm{Rp})$

$\mathrm{Q} \quad=$ Jumlah produksi (satuan unit)

\section{Keuntungan dan Profitabilitas}

Keuntungan usaha agroindustri olahan rumah tangga merupakan hasil akhir penerimaan dikurangi dengan biaya total produksi. Secara matematis keuntungan ditulis dengan rumus: $\boldsymbol{\pi}=\boldsymbol{T} \boldsymbol{R}-\boldsymbol{T C}$

Keterangan:

$\pi=$ Keuntungan $(\mathrm{Rp} /$ bulan $)$

$\mathrm{TR}=$ Total Penerimaan (Rp/bulan)

$\mathrm{TC}=$ Total Biaya $(\mathrm{Rp} / \mathrm{bulan})$

Sementara itu, profitabilitas merupakan perbandingan antara keuntungan dari penjualan dengan biaya total yang dinyatakan dengan persentase. Secara matematis dapat dirumuskan sebagai berikut:

Profitabilitas $=\pi / T C \times 100 \%$

Keterangan:

$\pi=$ Keuntungan usaha agroindustri olahan rumah tangga (Rp/bulan)

$\mathrm{TC}=$ Total biaya usaha agroindustri olahan rumah tangga (Rp/bulan)

Menurut Gasperz (1999) dalam Budiman, dkk (2012) criteria yang digunakan dalam penilaian profitabilitas adalah:

Proofabilitas $>1$, berarti usaha industri rumah tangga yang diusahakan memberi keuntungan dan layak untuk diusahakan Proofabilitas $=0$, berarti usaha industri rumah tangga yang diusahakan mengalami
Break Even Point (BEP) tidak untung dan tidak rugi

Proofabilitas $<1$, berarti usaha industri rumah tangga yang diusahakan tidak memberi keuntungan dan secara ekonomi tidak layak untuk diusahakan

\section{Analisis Efisiensi Usaha}

Perhitungan efisiensi usaha yang digunakan adalah Revenue Cost Ratio (R/C Ratio). $\mathrm{R} / \mathrm{C}$ Ratio adalah perbandingan antara penerimaan dengan biaya. Secara matematis dapat dituliskan sebagai berikut: $R C /$ rasio $=$ Total Penerimaan $(T R) /$ Total Biaya (TC)

$$
=\mathrm{TR} / \mathrm{TC}
$$

Dimana:

Jika $\mathrm{R} / \mathrm{C}>1$ maka usaha agroindustri menguntungkan untuk diusahakan.

Jika $\mathrm{R} / \mathrm{C}<1$ maka usaha agroindustri tidak menguntungkan untuk diusahakan. Jika $\mathrm{R} / \mathrm{C}=1$ maka usaha agroindustri impas, yaitu usaha memberikan jumlah penerimaan yang sama dengan jumlah yang dikeluarkan.

\section{Analisis Nilai Tambah}

Menurut Hayami Y ( 1987) ada dua cara menghitung nilai tambah, (1) nilai untuk pengolahan dan; (2) nilai tambah untuk pemasaran. Faktor-faktor yang mempengaruhi nilai tambah untuk pengolahan dapat dikelompokkan menjadi dua yaitu teknis dan faktor pasar. Faktor teknis yang mempengaruhi adalah kapasitas produk, jumlah bahan baku yang digunakan dan tenaga kerja, sedangkan faktor pasar yang mempengaruhi adalah harga output, upah tenaga kerja, harga bahan baku dan nilai input lain selain bahan baku dan tenaga kerja.

Faktor konversi metode hayami menunjukkan banyaknya produk olahan yang dihasilkan dari satu kilogram bahan baku. Koefisien tenaga kerja menunjukkan banyaknya tenaga kerja langsung yang diperlukan untuk mengolah satu satuan input. Nilai produk menunjukkan nilai 
output yang dihasilkan dari satu satuan input.

Nilai input lain mencakup nilai dari semua korbanan selain bahan baku dan tenaga kerja langsung yang digunakan selama produksi berlangsung.

Output adalah pengeluaran produk yang dihasilkan dalam satu kali proses produksi dihitung dalam satuan kilogram. Input adalah pemasukan bahan baku utama yang dibutuhkan dalam satu kali proses produksi yang dihitung dalam satuan kilogram. Tenaga kerja adalah jumlah orang yang melakukan proses produksi dalam satu kali proses produksi. Faktor konversi merupakan pembagian dari output dengan Input dalam satu kali proses produksi. Koefesien tenaga kerja diperoleh dari hasil bagi antara tenaga kerja dengan input.

Dasar perhitungan dari analisis nilai tambah adalah per kg hasil, standar harga yang digunakan untuk input/bahan baku dan produksi ditingkat pengolah/ produsen.

a. Analisis Nilai Tambah dengan rumus sebagai berikut (Sudiyono; 2004)

$$
\begin{aligned}
& \mathrm{NTp}=\mathrm{Na}-\mathrm{Ba} \ldots \ldots \ldots \ldots . . . \\
& \mathrm{Ba}=(\mathrm{Bb}+\mathrm{Bp}+\mathrm{Bbp})
\end{aligned}
$$

Keterangan :

NTp $=$ Nilai Tambah Produk (Rp)

$\mathrm{Na}=$ Nilai Produk Akhir $(\mathrm{Rp})$

$\mathrm{Ba}=$ Biaya antara $(\mathrm{Rp})$

$\mathrm{Bb}=$ Biaya bahan baku (Rp)

$\mathrm{Bp}=$ Biaya penyusutan alat $(\mathrm{Rp})$

$\mathrm{Bbp}=$ Biaya bahan penolong $(\mathrm{Rp})$

Rasio Nilai Tambah $(\mathrm{RNT})=\mathrm{NT} / \mathrm{NP}$

Dimana : $\mathrm{RNT}=$ Rasio nilai tambah (\%)

NT = Nilai Tambah (Rp)

$\mathrm{NP}=$ Nilai Produksi ( Rp ).

Keterangan :

a. Jika Rasio Nilai Tambah $>50 \%$, maka nilai tambah produk olahan tinggi

b. Jika Rasio Nilai Tambah $<50 \%$, maka nilai tambah produk olahan rendah

\section{HASIL DAN PEMBAHASAN}

\section{Gambaran Usaha Industri Rumah Tangga UMKM di Lombok Timur}

Sesuai dengan hasil pemetaan usaha mikro, kecil dan menengah kerjasama Dinas Koperasi UMKM Provinsi NTB dengan Badan Pusat Statistik Provinsi NTB tahun 2005 bahwa jumlah UMKM sebanyak 392.162 unit (tidak termasuk sektor pertanian) dengan penyerapan tenaga kerja sebanyak 508.636 unit, sedangkan data tahun 2006 menurut NTB dalam angka (BPS) jumlah UMKM sebanyak 544.607 unit, pada tahun 2015 bertambah sebanyak 1.080 unit, yang berasal dari Wira Usaha Baru sehingga jumlah UMKM per Desember 2015 menjadi 645.788 unit, dan sampai dengan Tahun 2016 bertambah sebanyak 1.200 unit yang berasal dari Wirausaha Baru sehingga jumlah UMKM sampai dengan tahun 2016 berjumlah 646.988 unit, tahun 2017 sebanyak 648.827 dan tahun 2018 sebanyak 648.987 seperti tampak pada tabel 38 .

Pembinaan pengusaha kecil dan menengah merupakan langkah yang sangat srategis untuk dikembangkan demi memperkokoh struktur perekonomian nasional dalam meningkatkan pendapatan masyarakat. Keberhasilan pembinaan usaha mikro kecil dan menengah sangat ditentukan oleh pendayagunaan secara optimal sumber daya yang tersedia seperti pendayagunaan sumber daya alam dan peningkatkan kualitas sumber daya manusia pengelola UMKM, pembinaan secara terpadu dari pemerintah serta dukungan masyarakat. Disamping itu dalam rangka pembinaan yang lebih berdaya guna dan berhasil guna perlu partisipasi /koordinasi asosiasi-asosiasi pengusaha kecil dan menengah yang ada. Rincian jumlah Usaha Mikro kecil, menengah dan Besar di Nusa Tenggara Barat per Kab/Kota, Perkembangan UMKM Di Kabupaten Lombok Timur Tahun 2015-2018 Berikut data perkembangan Usaha Mikro Kecil dan 
Menengah di Kabupaten Lombok Timur dari tahun 2014 sampai dengan tahun 2018

2014 (144.171), 2015 (160.790), 2016 (161.078), 2017 (161.254), 2018 (161.261). Kabupaten Lombok Timur merupakan kabupaten yang memiliki potensi hasil pertanian yang melimpah, hal ini dapat dilihat dari rata-rata pekerjaan masyarakat merupakan seorang petani. Produksi hasil pertanian di Kabupaten Lombok Timur yang cukup banyak tersebut menyebabkan munculnya berbagai agroindustri olahan hasil pertanian baik menjadi produk setengah jadi maupun menjadi produk yang sudah siap dikonsumsi. Hasil olahan tersebut dapat meningkatkan daya simpan dan nilai jual yang lebih tinggi dibandingkan dengan hasil pertanian segar. Dari data yang ada setiap tahunnya Usaha Mikro Kecil dan Menengah (UMKM) di kabupaten Lombok Timur mengalami penambahan dari $144 \quad 171$ unit usaha menjadi 161.261 pada tahun 2018 .

Kabupaten Lombok Timur merupakan kabupaten yang memiliki potensi hasil pertanian yang melimpah, hal ini dapat dilihat dari rata-rata pekerjaan masyarakat merupakan seorang petani. Produksi hasil pertanian di Kabupaten Lombok Timur yang cukup banyak tersebut menyebabkan munculnya berbagai agroindustri olahan hasil pertanian, baik menjadi produk setengah jadi maupun menjadi produk yang sudah siap dikonsumsi. Hasil olahan tersebut dapat meningkatkan daya simpan dan nilai jual yang lebih tinggi dibandingkan dengan hasil pertanian segar. Proses pembuatan untuk sampai menjadi produk membutuhkan input produksi berupa sarana produksi, peralatan, dan tenaga kerja. Dalam proses produksi diperlukan biaya produksi. Biaya produksi dibedakan menjadi dua yakni biaya eksplisit dan implisit. Biaya eksplisit seperti biaya sarana produksi, tenaga kerja luar keluarga (TKLK), biaya lain-lain dan biaya penyusutan alat. Biaya implisit mencakup bunga modal sendiri, sewa tempat sendiri, dan tenaga kerja dalam keluarga (TKDK). Selanjutnya produk yang sudah diproduksi akan dipasarkan dengan harga yang telah ditentukan sehingga akan didapat penerimaan sebagai hasil perkalian antara jumlah produksi dan harga. Agroindustri pengolahan di Kabupaten Lombok Timur berskala mikro dan kecil. Selain itu, jumlah permintaan produk tidak selamanya tetap. Permintaan tetap ketika hari biasa, namun dengan adanya pandemi pada saat ini permintaan menurun pada beberapa produk (tidak semua produk) sehingga jumlah produksi menurun. Oleh karena itu, penelitian ini bertujuan untuk melihat berapa nilai tambah dan efisiensi usaha pada agroindustri olahan rumah tangga di Kabupaten Lombok Timur.

\section{Proses Produksi Produk Industri Rumah Tangga}

Proses produksi usaha industri rumah tangga pada umumnya dilakukan di masing-masing rumah pemilik usaha dengan bermacam peralatan manual yang sederhana, Proses pembuatan untuk sampai menjadi produk membutuhkan input produksi berupa sarana produksi, peralatan, dan tenaga kerja. Dalam proses produksi diperlukan biaya produksi. Biaya produksi dibedakan menjadi dua yakni biaya eksplisit dan implisit. Biaya eksplisit seperti biaya sarana produksi, tenaga kerja luar keluarga (TKLK), biaya lain-lain dan biaya penyusutan alat. Biaya implisit mencakup bunga modal sendiri, sewa tempat sendiri, dan tenaga kerja dalam keluarga (TKDK).

Selanjutnya produk yang sudah diproduksi akan dipasarkan dengan harga yang telah ditentukan sehingga akan didapat penerimaan sebagai hasil perkalian antara jumlah produksi dan harga. Agroindustri pengolahan di Kabupaten Lombok Timur berskala mikro dan kecil. Selain itu, jumlah permintaan produk tidak selamanya tetap. Permintaan tetap ketika hari biasa, namun dengan adanya pandemi pada saat ini permintaan menurun pada 
beberapa produk (tidak semua produk) sehingga jumlah produksi menurun. Oleh karena itu, penelitian ini bertujuan untuk melihat berapa nilai tambah dan efisiensi usaha pada agroindustri olahan rumah tangga di Kabupaten Lombok Timur.

Usaha agroindustri olahan rumah tangga di Kabupaten Lombok Timur merupakan usaha yang menerapkan manajemen yang sederhana, dimana pengelolaan usaha tersebut sangat didominasi oleh pemilik usaha itu sendiri. Efisiensi usaha agroindustri tersebut dapat diketahui ketika usaha dapat mengelola penggunaan sarana produksi secara hemat. Tingkat efisiensi dapat digunakan sebagai tolok ukur dalam pengelolaan sarana produksi saat kegiatan proses pembuatan produk berlangsung. Ketika suatu usaha telah efisien secara teknis, maka pendapatan usaha akan meningkat. Kegiatan produksi ini memperoleh penerimaan yaitu dengan mengalikan total produksi dengan harga produksi. Hasil perhitungan penerimaan kemudian dikurangi dengan biaya total sehingga diperoleh pendapatan.

\section{Biaya Produksi}

Biaya produksi usaha agroindustri olahan rumah tangga per bulan merupakan jumlah dari biaya variabel per bulan dan biaya tetap per bulan. Yang termasuk dalam biaya variabel usaha agroindustri olahan rumah tangga ialah upah tenaga kerja, biaya bahan baku, biaya bahan penolong, dan biaya bahan bakar. Upah tenaga kerja termasuk dalam biaya variabel karena sebagian besar usaha agroindustri olahan rumah tangga di Lombok Timur menggunakan sistem upah borongan sekali produksi. Upah tenaga kerja bukan biaya yang setiap bulannya dikerluarkan, melainkan tergantung dari intensitas produksi. Selanjutnya, yang termasuk dalam biaya tetap ialah biaya penyusutan, sewa, biaya air, dan biaya listrik.

Besaran biaya produksi tergantung pada produksi apa yang dilakukan dan bahan-bahan apa yang digunakan. Usaha agroindustri pengolahan pisau tradisional menjadi usaha dengan total biaya tertinggi yaitu Rp.78.139.792,-/bulan. Biaya tersebut sebagian besar digunakan untuk membeli bahan baku utama yaitu kayu dan bahan penolong lainnya. Selain dari pembelian bahan baku, besaran biaya produksi juga tergantung pada skala produksi. Usaha agroindustri pengolahan serbat jahe juga memiliki biaya produksi yang tinggi yaitu Rp.46.571.333,-/bulan. Usaha agroindustri ini merupakan usaha skala kecil menengah karena berproduksi untuk memenuhi permintaan konsumen dalam dan luar kabupaten. Sementara itu, usaha agroindustri olahan rumah tangga dengan biaya produksi rendah yaitu kisaran Rp1.000.000 hingga Rpp.2.000.000 merupakan usaha mikro yang dijalankan hanya untuk memenuhi kebutuhan seharihari. Bahan baku produksinya juga relative murah dan mudah didapatkan.

Bila dirata-ratakan total biaya usaha agroindustri olahan rumah tangga di Lombok Timur ialah sebesar Rp.9.004.081,-/bulan. Dengan rincian total biaya variabel (variable cost) sebesar Rp.8.905.567,-/bulan dan total biaya tetap (fixed cost) sebesar Rp.98.515,-/bulan.

\section{Nilai Produksi}

Nilai produksi adalah nilai dari komoditas yang dihasilkan oleh sektor produksi, biasanya merupakan hasil perkalian dari kuantitas produksi (Q) dengan harga per unit $(\mathrm{P})$ komoditas tersebut. Definisi nilai produksi sama dengan definisi total penerimaan (total revenue) yaitu nilai penerimaan total yang diperoleh dari hasil perkalian antara jumlah produksi yang dihasilkan (Q) dengan harga jual produk (P). Namun nilai produksi per bulan tidak sama dengan total penerimaan per bulan. Karena pada kenyataannya tidak semua produksi yang diproduksi laku dalam satu bulan, khususnya produk non makananminuman. Kenyataan ini dapat dikesampingkan dan diasumsikan bahwa seluruh produk laku dalam satu bulan. 
Usaha agroindustri olahan rumah tangga di Lombok Timur yang memiliki nilai produksi tertinggi ialah usaha serbat jahe sebesar Rp.62.400.000,-/bulan. Sedangkan dari bidang non makanan-minuman, usaha yang memiliki nilai produksi tertinggi ialah usaha pisau tradisional sebesar Rp.93.000.000,-/bulan. Terdapat juga usaha-usaha dengan nilai produksi berkisar puluhan juta. Usaha-usaha tersebut umumnya merupakan usaha yang berproduksi penuh dalam satu bulan yaitu antara 20-30 kali per bulan atau usahausaha yang memang ditujukan untuk wirausaha. Oleh karena itu memiliki nilai produksi yang cukup besar. Sedangkan usaha-usaha yang memiliki nilai produksi ratusan ribu hingga jutaan ialah usahausaha mikro yang berproduksi kurang dari 20 kali per bulan. Usaha-usaha ini biasanya usaha berskala mikro yang diusahakan oleh ibu rumah tangga.

Bila rata-ratakan nilai produksi usaha agroindustri olahan rumah tangga di Lombok Timur ialah sebesar Rp.13.616.093,-/bulan. Bila nilai produksi sama dengan total penerimaan, maka usaha agroindustri olahan rumah tangga di Lombok Timur dapat dikategorikan sebagai usaha mikro karena total penerimaannya kurang dari Rp. 300 juta per tahun.

\section{Keuntungan dan Profitabilitas}

Keuntungan merupakan selisih dari total penerimaan (total revenue) dengan total biaya (total cost). Sementara profitabilitas adalah persentase keuntungan dari besaran biaya produksi. Semakin besar keuntungan usaha industri olahan rumah tangga , semakin besar pula profitabilitasnya.

Rata-rata pendapatan yang diperoleh pekerja informal dibawah Rp 2.000.000,sebanyak $\quad 46,67 \%$ dan $30,33 \%$ pendapatannya di atas Rp 3.000,000,Sedangkan pendapatan responden rata-rata di atas $R p$ 4.000.000, sebanyak $23 \%$. Usaha agroindustri olahan rumah tangga di kecamatan Selong kabupaten Lombok
Timur dengan keuntungan bervariasi yaitu antara Rp 2.000.000 sebulan sampai dengan Rp 4..000.000,- per bulan. Perbedaan keuntungan yang diterima tergantung dari jenis produk dan harga jual produk yang dihasilkan oleh industri rumah tangga dalam membuat produk olahan makanan matang umumnya. Seperti jajanan basah, dengan perkiraan keuntungan rata-rata per bulan sebesar Rp.4.553.104,- dan panganan jenis kerupuk ataupun keripik rata-rata pendapatannya sebesar Rp 2.500.000 per bulan. Usaha agroindustri olahan rumah tangga seperti usaha jajanan basah, kentang goreng, bakso cilok, dan usaha lain yang menggunakan bahan baku sederhana, proses produksi sedehana serta intensitas produksi penuh per bulan memiliki potensi keuntungan dan profitabilitas yang besar. Sementara itu, pada kenyataan terdapat usaha agroindustri olahan industri di kecamatan Selong kabupaten Lombok Timur ada juga yang mengalami kerugian. Kerugian dialami karena penetapan harga jual yang tidak memperhatikan total biaya dalam produksi. Yang artinya harga jual yang ditetapkan tidak diperhitungkan dengan baik.

\section{Efisiensi Usaha}

Usaha agroindustri olahan rumah tangga di Kabupaten Lombok Timur merupakan usaha yang menerapkan manajemen yang sederhana, dimana pengelolaan usaha tersebut sangat didominasi oleh pemilik usaha itu sendiri. Efisiensi usaha agroindustri tersebut dapat diketahui ketika usaha dapat mengelola penggunaan sarana produksi secara hemat. Tingkat efisiensi dapat digunakan sebagai tolok ukur dalam pengelolaan sarana produksi saat kegiatan proses pembuatan produk berlangsung. Ketika suatu usaha telah efisien secara teknis, maka pendapatan usaha akan meningkat. Kegiatan produksi ini memperoleh penerimaan yaitu dengan mengalikan total produksi dengan harga produksi. Hasil perhitungan penerimaan kemudian 
dikurangi dengan biaya total sehingga diperoleh pendapatan.

Efisiensi usaha agroindustri olahan rumah tangga dapat ditentukan dari Revenue Cost Ratio (R/C Ratio). R/C Ratio adalah perbandingan antara penerimaan dengan biaya. Semakin besar R/C Rasio (lebih besar dari 1) maka semakin menguntungkan usaha agroindstri tersebut untuk diusahakan. Tidak semua usaha agroindustri olahan rumah tangga di Lombok Timur memiliki efisiensi bernilai $>1$. Namun sebagian besar usaha agroindustri olahan rumah tangga di Lombok Timur memiliki efisiensi atau $\mathrm{R} / \mathrm{C}$ Rasio $>1$, yang artinya sebagian besar usaha efisien dan menguntungkan untuk diusahakan. Usaha agroindustri olahan rumah tangga dengan $\mathrm{R} / \mathrm{C}$ Rasio tertinggi ialah usaha pengolahan jajanan basah. Efisiensi usaha ini tinggi karena dapat mengolah bahan baku tepung dan bahan penolong lainnya menjadi berbagai macam jajanan basah yang bernilai jual tinggi.

Sementara itu terdapat beberapa usaha agroindustri olahan rumah tangga di Lombok Timur yang memiliki efisiensi atau $\mathrm{R} / \mathrm{C}$ Rasio $\leq 1$. Usaha-usaha tersebut diantaranya usaha pengolahan keripik bayam, kerupuk terigu, kue temerodok,kue serabi, keripik ubi ungu, jajan bantal, keripik pisang, . Usaha-usaha tersebut terhitung tidak efisien karena dalam penetuan harga jual produsen tidak memperhitungkan total biaya produksi dengan cermat. Sehingga total penerimaan (total revenue) lebih kecil dari total biaya (total cost). Jika perhitungan biaya tidak dilakukan dengan cermat dan harga jual tidak ditingkatkan maka usaha-usaha tersebut tidak menguntungkan untuk diusahakan.

\section{Nilai Tambah Usaha Agroindustri Olahan Rumah Tangga}

Nilai tambah merupakan selisih dari nilai produksi (penjualan hasil produksi) dengan intermediate cost (biaya bahan baku dan biaya input lain yang menunjang dalam proses produksi selain biaya tenaga kerja). Nilai tambah muncul karena terdapat proses pengolahan yang membuat produk dapat disimpan lebih lama. Bahan-bahan penolong lainnya juga ditambahkan dalam proses produksi. Berdasarkan analisis nilai tambah yang dilakukan dapat diketahui berapa besar nilai tambah yang dihasilkan dari proses pengolahan hasil pertanian menjadi produk pada agroindustri di Kabupaten Lombok Timur.

Agroindustri merupakan salah satu industri yang mampu memberikan nilai tambah (value added) bagi produk pertanian. Analisis pengolahan produk pertanian dilakukan dengan cara sederhana yaitu melalui perhitungan nilai tambah perkilogram bahan baku untuk satu kali proses produksi. Nilai tambah adalah selisih dari nilai output dengan biaya bahan dan pengolahan input. Penelitian ini bertujuan untuk menentukan nilai tambah pada setiap proses pengolahan usaha agroindustri rumah tangga di Lombok Timur dengan menggunakan metode Hayami. Analisis nilai tambah berguna untuk menaksir balas jasa yang diterima para pelaku usaha agroindsutri.

Berikut disajikan tabel hasil perhitungan nilai tambah dan rasio nilai tambah dari usaha agroindustri olahan rumah tangga UMKM di Kabupaten Lombok Timur pada November 2020. 
Tabel 4. Nilai Tambah dan Rasio Nilai Tambah Usaha Agroindustri Olahan Rumah Tangga di Kabupaten Lombok Timur, November

\begin{tabular}{|l|l|c|c|l|}
\hline No & \multicolumn{1}{|c|}{ Jenis Usaha } & Nilai Tambah (NT) & $\begin{array}{c}\text { Ratio Nilai } \\
\text { Tambah (\%) }\end{array}$ & $\begin{array}{c}\text { Efisiensi } \\
\text { Usaha }\end{array}$ \\
\hline 1 & Serabi & 14.856 & 49,52 & Rendah \\
\hline 2 & Bakso Cilok & 241.680 & 81,03 & Tinggi \\
\hline 3 & Kue Bawang & 119.550 & 69,64 & Tinggi \\
\hline 4 & Keripik Singkong & 16.139 & 62,57 & Tinggi \\
\hline 5 & Pisang Goreng & 33.583 & 73,01 & Tinggi \\
\hline 6 & Jajan Basah & 352.853 & 98,0 & Tinggi \\
\hline 7 & Pagar Bambu & 320.000 & 86,49 & Tinggi \\
\hline 8 & Keripik Pisang & 36.738 & 64,75 & Tinggi \\
\hline 9 & Kerupuk Terigu & 11.950 & 39,0 & Rendah \\
\hline 10 & Kue kemerodok & 66.650 & 46,50 & Rendah \\
\hline 11 & Aren Coffe Lombok & 190.112 & 70,98 & Tinggi \\
\hline 12 & Rengginang & 22.875 & 71,58 & Tinggi \\
\hline 13 & Serbat Jahe & 34.154 & 34,60 & Rendah \\
\hline 14 & Batagor & 77.750 & 51,58 & Tinggi \\
\hline 15 & Kacang Goreng & 18.720 & 46,80 & Rendah \\
\hline
\end{tabular}

Sumber : Data Penelitian (2020)

Tidak semua usaha agroindustri olahan rumah tangga dikecamatan Selong Lombok Timur mempunyai nilai tambah yang positif. Berdasarkan tabel 4.2 perhitungan nilai tambah dan rasio nilai tambah usaha agroindustri olahan rumah tangga di kecamatan Selong Kabupaten Lombok Timur pada bulan November 2020 data di atas menunjukkan bahwa usaha yang mempunyai nilai tambah dan rasio nilai tambah usaha agroindustri olahan rumah tangga tertinggi dan di atas $50 \%$ ( RNT $>50 \%$ ) yaitu pada usaha bakso cilok, kue bawang, keripik singkong, gorengan, jajan basah pagar bambu, keripik pisang, aren coffe Lombok dan rengginan berada pada kategori nilai tambah yang dikaregorikan tinggi. Sedangkan usha industri rumah tangga lainnya seperti olahan makanan serabi,kerupuk terigu, kue kemerodok, serbat jahe dan kacang goreng memiliki rasionilai tambah dibawah $50 \%$ (RNT $<50 \%$ ) artinya usaha industri yang dikelola oleh rumah tangga rasio nilai tambahnya rendah dan ini disebabkan karena kurang memperhitungkan biayabiaya input yang dikeluarkan dengan hasil yang diterima dari hasil penjualan produknya dalam artian harga produk yang di jual terlalu rendah sehingga tidak dapat menutupi biaya produksi. Secara ekonomi bahwa usaha industri rumah tangga ini tidak efisien dari hasil perhitungan R/C Rationya dibawah atau $<1$, artinya usaha ini tidak layak untuk diusahakan. Namun karena usaha ini merupakan usaha rumah tangga yang dikelola bersama anggota keluarga maka mereka tetap berproduksi meskipun dengan pendapatan yang di raihnya kecil dan dapat untuk biaya hidup sehari hari disamping pendapatan lain-lain yang diterima oleh rumah tangga.

Hasil analisis beberapa usaha agroindustri olahan rumah tangga yang mengalami nilai tambah negatif, hal ini artinya proses produksi membuat nilai output semakin menurun. Usaha agroindustri olahan rumah tangga UMKM yang mengalami nilai tambah negatif ini hendaknya lebih meningkatkan kemanfaatan input yang digunakan dengan produk yang dihasilkan dan harga jual, sehingga akan meningkatkan nilai tambah produk dan rasio nilai tambahnya prosentasenya akan meningkat. 


\section{KESIMPULAN DAN SARAN}

\section{Kesimpulan}

Dari hasil pembahasan pada penelitian ini maka dapat ditarik beberapa kesimpulan terkait dengan kegiatan Usaha Industri rumah tangga UMKM di kecamatan Selong Kabupaten Lombok Timur di era COVID - 19 sebagai berikut : a. Profil usaha industri rumah tangga UMKM di kecamatan Selong Kabupaten Lombok Timur sebanyak 15 unit usaha sebahagian besar bergerak pada industri olahan makanan yang bahan bakunya menggunakan hasil-hasil produk pertanian dan usaha ini dikelola sendiri oleh responden.

b. Kajian tentang produksi dan biaya produksi jika diakaitkan dengan pendapatan yang diterima usaha industri rumah tangga UMKM ini masih rendah yaitu kisarannya antara $\mathrm{Rp} \quad 2.000,000$ sampai dengan Rp 4,000.000,- sebulan, dengan tingkat efisien usaha beberapa unit usaha rendah yaitu dibawah satu $(\mathrm{R} / \mathrm{C}$ Rasionya $<1)$, usaha ini tidak layak untuk diusahakan secara ekonomi.

c. Usaha industri rumah tangga sebagian besar atau $67 \%$ dari responden memiliki nilai tambah usaha agroindustri olahan rumah tangga tertinggi dan di atas 50\% ( RNT $>50 \%$ ) yaitu pada usaha bakso cilok, kue bawang, keripik singkong, gorengan, jajan basah pagar bambu, keripik pisang, aren coffe Lombok dan rengginan berada pada kategori nilai tambah yang tinggi.

\section{Saran}

a. Untuk meningkat pendapatan usaha perlu dilakukan variasi produk yang lebih diminati pasar konsumen dengan menambah varian-varian baru yang memiliki nilai jual yang tinggi.

b. Secara ekonomi baha usaha industri rumah tangga ini tidak efisien, dan perlu melakukan perhitungan bisnis yang cermat dan tepat guna menghindari kerugian dalam usahanya. c. Beberapa unit usaha industri rumah tangga olahan memiliki nilai tambah yang cukup tinggi dan ini kedepan dapat terus ditingkat penggunaan input untuk memberikan nilai tambah yang tinggi.

\section{REFERENSI}

Arikunto, Suharsini.2006. Prosedur Penelitian. Suatu pendekatan Praktik. PT. Reneka Cipta. Jakarta

Aryo Demarto,dkk.2003. Sektor informal alternatip kesempatan kerja Bagi Golongan Berpendidikan Rendah. Makalah Diklat Universitas Sebelas Maret.

Kartasasmita M. 2011. Pengertian Agroindustri . Blokspot.com. 2011

Mubyarto.1998. Konsep Biaya Industri Kecil. Gramedia Jakarta

Nasir, Mohammad. 2009. Metode Penelitian. Graha Indonesia. Jakarta.

Putong Iskandar. 2002. Pengantar Ekonomi Mikro dan Makro. Galia Indonesia

Santri Y,M. 2009. Analisis Usaha Agroindustri Keripik Belut di Kabupaten Klaten. Program Studi Agribisnis Fakultas Pertanian Universitas Sebelas Maret Surakarta.

Sudiyono. 2004. Pemasaran Pertanian .UMM.Malang

Sukartawi. 2003. Agribisnis. Teori dan Aplikasinya. PT. Raja Grafindo Persada Jakarta

Mar'atissholikhah, U., Darsono, \& Nurjayanti, E. D. (2013). Analisis nilai tambah industri keripik tempe skala rumah tangga (Studi Kasus Desa Lerep Kecamatan Ungaran Barat Kabupaten Semarang). Mediagro, 9(2), 24-34.

Nurmedika, N., Marhawati, M., \& Alam, M. N. (2013). Keripik Nangka Pada Industri Rumah Tangga Tiara Di Kota Palu. Agrotekbis, 1(3), 267-273.

Rahman, S. (2015). Analisis Nilai Tambah Agroindustri Chips Jagung. Jurnal Aplikasi Teknologi Pangan, 4(3), 108-111. 
Rangkuti, K., Ainul, M., \& Andini

Dwayani, P. (2015). Analisis nilai

tambah keripik singkong pada

Kelompok Usaha Keluarga (KUK)

Desa Sipare-Pare. Agrium, 19(2),

116-121.

Sari, I. R. M., Zakaria, W. A., \& Affandi,

M. I. (2015). Kinerja produksi dan

nilai tambah agroindustri emping melinjo Di Kota Bandar Lampung. JIIA, vol 3(1)

Waryat, W., Muflihani, Y., \& Mayasari, K. (2008). Analisis Nilai Tambah dan Usaha Pengolahan Tepung Sukun Sebagai Upaya Peningkatan Pendapatan Petani. Jurnal Agraris, vol 2(2) 